\title{
RELATIONSHIP BETWEEN SEED VIABILITY LOSS AND SEED BANK REDUCTION OF OROBANCHE AEGYPTIACA PERS. USING NON-HOST CROPS
}

\author{
Bipana Devi Acharya \\ Department of Botany, Amrit Campus, Lainchor, Kathmandu \\ Email: bipanaacharya@gmail.com
}

\begin{abstract}
Orobanche spp. are serious and difficult weed to control to many economically important plants. The seed bank of this noxious weed in soil can be reduced by using trap crop. But all the seed bank reduction is not due to trap crop only; some reduction is also contributed by edaphic and/or pathogenic factors. So in the present study, the relationship between reduction in Orobanche seed bank in soil and loss of seed viability due to trap crop has been investigated in pots and natural infested fields at Vedabari (Field A) and Beldia (Field B). Results of viability loss and seed bank reduction indicated that nearly $11 \%$ to $25 \%$ of the reduction of seed density of Orobanche in soil is contributed by seed viability loss due to trap crops. On combining data of all three experiments, it was found that the loss of seed viability in Orobanche due to combined effects of treatments with test crops was nearly $24 \%$. When the value obtained from viability loss and seed bank reduction is compared with the value obtained in control treatment, it is found that the contribution of edaphic factors for seed bank reduction is about $76 \%$ and that of tested trap crops is about $24 \%$, respectively.
\end{abstract}

Key words: Orobanche, seed bank, viability loss.

\section{INTRODUCTION}

Some seed bearing plants are true parasite or holo-parasite as chlorophyll is entirely lacking in them and are dependent upon other green plants to which they are attached for their food materials. Genus Orobanche is one of such holo-parasitic plants with about 150 species (Musselman 1980) . This genus is supposed to be very difficult weed to control as they have tremendous potential of seed production of up to 500,000 seeds/plant in Orobanche crenata (Cubero and Moreno 1979). Their seeds are very tiny $(0.25-0.3 \mathrm{~mm}$ diameter) and can remain viable possibly up to 20 years in soil in absence of suitable host (Kadry and Tewfic 1956, Cubero and Moreno 1979, Puzzilli 1983).
Orobanche spp. are serious weed of many economically important plants because of their complex life cycle they are very difficult to control. There are several discrete steps in the life cycle; production of a large number of seeds that require a post-ripening period as well as warm and moist conditions, induction of germination by hostderived stimulants, haustorial initiation by hostplant, haustorium inducers, attachment to the host root and penetration, establishment of contact with host vascular system, subterranean development, emergence, and flowering. The most serious damage to host crops occurs underground before emergence (Parker and Riches 1993). The seeds of 
Orobanche is triggered by root exudates of host and some non-host plants (Brown et al. 1951, Abbes et al. 2008). Methanolic extracts of many Chinese herbal species effectively stimulated seed germination among the Orobanche minor, $O$. cumana and $O$. aegyptiaca, even though they were not the typical hosts (Ma et al. 2012) and can serve as potential trap crops.

Trap crops or non-host plants may stimulate the germination of Orobanche seed but can not infect and thus reduces density of seeds in soil due to suicidal germination. Hence it can be hypothesized that Orobanche seed density in soil is dependent on its viability, or in other words, Orobanche seed viability loss will reduce seed bank in the soil. Therefore, an attempt has been made to study the relationship between reduction of Orobanche seed bank and viability loss due to different non-host crops in naturally infested soil.

\section{MATERIALS AND METHODS}

The experiments were conducted in Nawalparasi District, an inner Tarai region of Nepal, where infection of Orobanche sp. was fairly high . Two sites- Site A (at Vedabari) and Site B (at Beldia) were selected, both of which were farmer's fields hired for tori growing season. Pots and field experiments were conducted simultaneously in site A (Vedabari) but in site B (Beldia) it was limited to field experiments only. The experiments to study the effects of different non-host crops on Orobanche seed viability was overlapped in the same pots, and plots designed for the seed bank studies.

Pot experiments: Altogether, 22 winter crops were tested for pot experiments. The pot mixture included: a) soil collected from naturally infested field by Orobanche seeds, b) Fertilizers (N-0.8 $\mathrm{g} / \mathrm{kg}, \mathrm{P} 1.2 \mathrm{~g} / \mathrm{kg}$ and $\mathrm{K} 0.6 \mathrm{~g} / \mathrm{kg}$ of soil) and, c) compost. The earthen pots of size 9 inches diameter were first moistened with water and then filled with soil mixture. About $3 / 4^{\text {th }}$ portions of pots were buried into the soil to avoid rapid fluctuation of soil temperature and moisture.

Seeds or seedlings of test crops were collected from the local market. Crop seeds were sown 3-4 $\mathrm{cm}$ deep in the soil. Tubers of potato, bulb-lets of garlic and, seedlings of onion, egg plants and that of chili were planted in the pots. To avoid dehydration of the germinating seeds, regular watering was done. There were three replications for each treatment, including control pots.Soil samples for quantitative estimation of Orobanche seeds were collected from each pot at the time of crop sowing and after harvest.

Field Experiments: Altogether, 21 winter crops were tested for field experiments. The fields at Site A and Site B were both rain fed with maize and tori as summer and winter crops, respectively. The fields were prepared by ploughing twice and were set in randomized complete block design with 22 treatments including control. All the treatments were in triplicates.

The field had homogenous nutrient and moisture regimes. The soil type in field A was sandy-loam with $71 \%$ sand, $22 \%$ silt, $7 \%$ clay and $2.01 \%$ total organic matters. Soil nitrogen was $0.151 \%$, phosphorus $189 \mathrm{~kg} / \mathrm{ha}$, potassium 516 $\mathrm{kg} / \mathrm{ha}$, and the soil $\mathrm{pH}$ was 6.2. Manuring was done with animal dung. Unlike the Field-A, the soil type in Field-B was loam with $49 \%$ sand, $30 \%$ silt, $21 \%$ clay and $2.28 \%$ total organic matters. And Nitrogen was $0.132 \%$, Potassium $724 \mathrm{~kg} / \mathrm{ha}$, and Phosphorous $161 \mathrm{~kg} / \mathrm{ha}$. The soil $\mathrm{pH}$ was 6.7 . The mean soil temperature of experimental area varied from $12^{\circ} \mathrm{C}$ to $23^{\circ} \mathrm{C}$ in the morning (at $6 \mathrm{AM}$ ) and from $15^{\circ} \mathrm{C}$ to $25^{\circ} \mathrm{C}$ in the afternoon (at $1 \mathrm{PM}$ ) during the study period.

\section{Soil sample collection and seed bank estimation}

Soil was sampled two times from each plot: first immediately after sowing and, the second after harvest. The sampling spots were located between plant rows and there were three equally spaced

ECOPRINT VOL 20, 2013 
spots between rows. Soil was sampled using auger reaching up to $15 \mathrm{~cm}$ deep. Soil sampled from different spots of a plot are mixed together and divided and re-divided and, finally one $\mathrm{kg}$ of soil was collected for laboratory estimation of Orobanche seeds (Composite soil sampling). Orobanche seed recovery from soil was done following the method of Asworth (1976) with slight modification (Khattri 1997, Acharya et al. 2003). The percentage reduction of Orobanche seeds were determined from the difference of initial and final Orobanche seed count before sowing and after harvest, respectively.

\section{Viability of Orobanche seeds buried in pots and plots}

To study the effect of trap crops on viability, initially the seed viabiliy of $O$. aegyptiaca seeds collected from tori fields was determined by the method of Aalders and Pieters (1986), with slight modification, using $1 \%$ aqueous solution of $2,3,5$ Triphenyl Tetrazolium Chloride, 2\% sodium hypochlorite. The viability of $O$. aegyptiaca seeds was estimated corresponding to the number of stained red seeds and it was considered as initial viability for the present study.

Then, the seed bags were prepared by tying about $10 \mathrm{mg}$ of $O$. aegyptiaca seeds in muslin cloth with nylon thread. Seed bags were buried 10 $\mathrm{cm}$ deep in each pots and plots soil after final thinning. The seed bags were taken out after the harvest of crops and final viability of seeds tested. All the treatments were in triplicates. The initial and final viability of Orobanche seeds in different pots and plots including fallow (as control) was compared for viability loss. Viability loss due to non-host crop was calculated by deducting the viability loss obtained due to edaphic factors and test crops together from the viability (mean) of each non-host treatment.
Statistical Analysis: All data obtained from seed bank and viability study were processed for ANOVA followed by Duncan Multiple range Test using statistical program SPSS 15. Regression analysis between viability loss and seed bank reduction were conducted to understand the relationship between them.

\section{RESULTS}

Results of seed bank reduction and viability loss due to different investigated trap crops in pot and field experiments are given in Tables 1, 2 and 3. Comparison of seed bank in soil before sowing and after harvest of different test crops showed that the number of Orobanche seeds reduced in all cases, even in fallow pots or plots (controls). Mean viability loss of buried Orobanche seed due to soil factor and non-host crop together was 30.41\%, $30.43 \%$ and $23.11 \%$ in pot experiments, Field A and Field B, respectively. Viability loss of Orobanche seeds buried in the soil was found to be different with different test crops. Besides this, the change of coloration of fungal or bacterial infested Orobanche seeds into black was observed.

\section{Pot experiment}

Of the 22 crops investigated in pot experiment, the reduction of Orobanche seed bank was found to be significant $(\mathrm{P}=0.05)$ compared to control pots in cumin (Cuminum cyminum), carrot (Daucas carrota), fennel (Foeniculum vulgare), barley (Hordeum vulgare), lentil (Lens culinaris), linseed (Linum usitatissimum), radish (Raphanus sativus) and maize ( Zea mays) (Table 2). The reduction was highest in lentil (54.27 \pm 8.63 in seed density).

The viability of the Orobanche seeds before burying in soil was regarded as initial viability and was found to be $86.44 \%$. The viability of buried Orobanche seeds after crop harvest was reduced significantly $(\mathrm{P}=0.05)$ in all cases (Table 1$)$ except in carrot. Viability loss was recorded highest in pots with radish $(56.68 \%)$ and it was above $35 \%$ in pots with chilli, chickpea, cumin and maize. 
Table 1. Percentage reduction in seed bank, viability of Orobanche aegyptiaca seeds and its reduction after crop harvest in pot experiments. Same letters followed after the mean \pm standard deviation in a column do not differ significantly at $\mathbf{P}=0.05$ according to Duncan's Multiple range tests followed after ANOVA.

\begin{tabular}{|c|c|c|c|c|c|}
\hline \multirow[t]{2}{*}{ Botanical name } & \multirow{2}{*}{$\begin{array}{l}\text { Common } \\
\text { name }\end{array}$} & \multirow{2}{*}{$\begin{array}{l}\text { Reduction }(\%) \text { in } \\
\text { seed density }\end{array}$} & \multirow{2}{*}{$\begin{array}{l}\text { Viability }(\%) \\
\text { Mean } \pm \text { Sd. }\end{array}$} & \multicolumn{2}{|c|}{ Viability loss (\%) } \\
\hline & & & & (A) & (B) \\
\hline Allium cepa $\mathrm{L}$. & Onion & $22.00 \pm 3.78 \mathrm{ABCD}$ & $55.75 \pm 5.94 \mathrm{~B}$ & 30.69 & 6.79 \\
\hline Allium sativum $\mathrm{L}$. & Garlic & $15.15 \pm 5.08 \mathrm{~A}$ & $52.56 \pm 9.90 \mathrm{~B}$ & 33.88 & 9.98 \\
\hline Capsicum furtescens $\mathrm{L}$. & Chili & $11.64 \pm 0.84 \mathrm{~A}$ & $50.20 \pm 4.02 \mathrm{~B}$ & 36.24 & 12.34 \\
\hline Cicer arietinum $\mathrm{L}$. & Chickpea & $23.64 \pm 2.99 \mathrm{ABCD}$ & $51.16 \pm 9.55 \mathrm{~B}$ & 35.28 & 11.38 \\
\hline Coriandrum sativum $\mathrm{L}$. & Coriander & $22.41 \pm 3.69 \mathrm{ABCD}$ & $56.95 \pm 4.87 \mathrm{~B}$ & 29.49 & 5.59 \\
\hline Cuminum cyminum $\mathrm{L}$. & Cumin & $31.29 \pm 8.98 \mathrm{DE}$ & $49.91 \pm 17.20 \mathrm{~B}$ & 42.81 & 20.96 \\
\hline Daucas carrota $\mathrm{L}$. & Carrot & $29.53 \pm 5.47 \mathrm{BCDE}$ & $70.07 \pm 8.25 \mathrm{BC}$ & 16.37 & -7.53 \\
\hline Fagopyrum esculentum Moench & Buckwheat & $21.86 \pm 8.64 \mathrm{ABCD}$ & $53.85 \pm 13.62 \mathrm{~B}$ & 32.59 & 8.69 \\
\hline Foeniculum vulgare Mill & Fennel & $37.33 \pm 5.91 \mathrm{EF}$ & $62.84 \pm 3.87 \mathrm{~B}$ & 23.6 & -0.3 \\
\hline Helianthus annus $\mathrm{L}$. & Sunflower & $14.62 \pm 9.16 \mathrm{~A}$ & $67.80 \pm 7.03 \mathrm{~B}$ & 18.64 & -5.26 \\
\hline Hordeum vulgare $\mathrm{L}$. & Barley & $31.33 \pm 8.58 \mathrm{DE}$ & $57.79 \pm 6.23 \mathrm{~B}$ & 28.65 & 4.75 \\
\hline Lens culinaris Medic. & Lentil & $54.27 \pm 8.63 \mathrm{G}$ & $51.65 \pm 19.47 \mathrm{~B}^{*}$ & 34.79 & 10.89 \\
\hline Linum usitatissimum $\mathrm{L}$. & Linseed & $30.05 \pm 2.84 \mathrm{CDE}$ & $62.22 \pm 7.28 \mathrm{~B}^{*}$ & 24.22 & 0.32 \\
\hline Phaseolus vulgaris $\mathrm{L}$. & French bean & $14.49 \pm 5.33 \mathrm{~A}$ & $64.04 \pm 8.32 \mathrm{~B}$ & 22.4 & -1.5 \\
\hline Pisum sativum $\mathrm{L}$. & Pea & $20.56 \pm 3.38 \mathrm{ABCD}$ & $57.13 \pm 8.02 \mathrm{~B}$ & 29.31 & 5.41 \\
\hline Raphanus sativus $\mathrm{L}$. & Radish & $42.28 \pm 5.29 \mathrm{~F}$ & $29.76 \pm 10.31 \mathrm{~A}$ & 56.68 & 32.78 \\
\hline Solanum melongena $\mathrm{L}$. & Egg plant & $17.68 \pm 10.95 \mathrm{AB}$ & $57.01 \pm 16.59 \mathrm{~B}^{*}$ & 29.43 & 5.53 \\
\hline Solanum tuberosum $\mathrm{L}$. & Potato & $19.34 \pm 6.08 \mathrm{ABCD}$ & $51.70 \pm 20.21 \mathrm{~B}^{*}$ & 34.74 & 10.84 \\
\hline Trigonella foenum- graecum $\mathrm{L}$. & Fenugreek & $22.51 \pm 0.69 \mathrm{ABCD}$ & $52.59 \pm 8.85 \mathrm{~B}$ & 33.85 & 9.95 \\
\hline Triticum aestivum L. & Wheat & $18.79 \pm 5.47 \mathrm{ABC}$ & $58.68 \pm 10.98 \mathrm{~B} *$ & 27.76 & 3.86 \\
\hline Vicia faba $\mathrm{L}$. & Faba bean & $18.04 \pm 5.67 \mathrm{AB}$ & $60.57 \pm 8.00 \mathrm{~B}$ & 25.87 & 1.97 \\
\hline Zea mays L. & Maize & $28.05 \pm 6.70 \mathrm{BCDE}$ & $50.46 \pm 14.52 \mathrm{~B} * *$ & 35.98 & 12.08 \\
\hline Control & & $15.09 \pm 3.47 \mathrm{~A}$ & $62.54 \pm 5.75 \mathrm{~B}$ & & \\
\hline Initial Viability & & & $86.44 \pm 2.29 \mathrm{C}$ & & \\
\hline
\end{tabular}

* Seeds with black embryo in one pot; ** Seeds with black embryo in two pots

Viability loss due to $(\mathrm{A})=$ soil factors and test crops, $(\mathrm{B})=$ test crops only

\section{Field A}

The mean percentage reduction of Orobanche seed bank in Field-A was found to be $18.86 \pm 6.70$. Lowest percentage of Orobanche seed bank reduction was recorded in plots with chili $(8.20 \pm 3.16 \%)$ and highest percentage in plots with radish (34.69 \pm 9.09$)$. Out of 21 test crops investigated, seed bank was reduced significantly $(\mathrm{P}=0.05)$ in onion, chickpea, radish, fennel, lentil and linseed than in control plots (Table 2).

Viability of Orobanche seeds buried in soil showed significant decrease $(\mathrm{P}=0.05)$ in all cases 
including fallow in comparison to initial viability. The reduction of Orobanche seed viability was highest in plots grown with fenugreek $(42.46 \%)$, and lowest in plots with buckwheat (68.70\%) (Table 2). When data of Orobanche seed viability loss in different test crops were compared with that of control plots, it was found that the viability reduced above $35 \%$ in plots with onion, chili, pea and fenugreek.

\section{Field B}

The mean reduction in Orobanche seed bank in the field B was found to be $19.24 \pm 7.62 \%$ and the reduction was highest in lentil $(35.39 \pm 1.83 \%$.) and lowest in chili $(6.41 \pm 5.28 \%)$. Out of 21 crops investigated, Orobanche seed bank was reduced significantly $(\mathrm{P}=0.05)$ in fennel, lentil, linseed, radish and barley compared to control plots (Table $3)$.

Table 2. Percentage reduction in seed bank, viability of Orobanche aegyptica seeds (\%) and its reduction after crop harvest in Field-A (Vedabari). Same letters followed after the mean \pm standard deviation in a column do not differ significantly at $P=0.05$ according to Duncan's Multiple range tests followed after ANOVA.

\begin{tabular}{|c|c|c|c|c|c|}
\hline \multirow[t]{2}{*}{ Botanical name } & \multirow{2}{*}{$\begin{array}{l}\text { Common } \\
\text { name }\end{array}$} & \multirow{2}{*}{$\begin{array}{l}\text { Reduction }(\%) \text { in } \\
\text { seed bank }\end{array}$} & \multirow{2}{*}{$\begin{array}{c}\text { Viability }(\%) \\
\text { Mean } \pm \text { Sd }\end{array}$} & \multicolumn{2}{|c|}{ Viability loss (\%) } \\
\hline & & & & (A) & (B) \\
\hline Allium cepa $\mathrm{L}$. & Onion & $23.73 \pm 3.00 \mathrm{CDEFGH}$ & $47.29 \pm 19.34 \mathrm{ABC}^{* *}$ & 39.15 & 16.26 \\
\hline Allium sativum $\mathrm{L}$. & Garlic & $10.47 \pm 1.51 \mathrm{AB}$ & $53.59 \pm 8.18 \mathrm{ABCDE}$ & 32.85 & 9.96 \\
\hline Capsicum frutescens $\mathrm{L}$. & Chili & $8.20 \pm 3.16 \mathrm{~A}$ & $44.74 \pm 6.06 \mathrm{AB}^{* *}$ & 41.70 & 18.81 \\
\hline Cicer arietinum $\mathrm{L}$. & Chickpea & $20.72 \pm 5,15 \mathrm{BCDEFG}$ & $52.65 \pm 5.05 \mathrm{ABCDE}^{*}$ & 33.79 & 10.9 \\
\hline Coriandrum sativum $\mathrm{L}$. & Coriander & $17.25 \pm 7.84 \mathrm{ABCDEF}$ & $51.49 \pm 5.61 \mathrm{ABCDE}$ & 34.95 & 12.06 \\
\hline Daucas carrota $\mathrm{L}$. & Carrot & $19.44 \pm 5.85 \mathrm{ABCDEF}$ & $61.13 \pm 4.74 \mathrm{DEFG}$ & 25.31 & 2.42 \\
\hline Fagopyrum esculentum Moench & Buckwheat & $19.17 \pm 3.63 \mathrm{ABCDEF}$ & $68.70 \pm 5.54 \mathrm{G}^{*}$ & 17.74 & -5.15 \\
\hline Foeniculum vulgare Mill. & Fennel & $31.01 \pm 9.58 \mathrm{GH}$ & $53.63 \pm 6.29 \mathrm{ABCDE}^{* *}$ & 32.81 & 9.92 \\
\hline Helianthus annus L. & Sunflower & $14.22 \pm 7.64 \mathrm{ABCDE}$ & $55.05 \pm 10.17 \mathrm{ABCDEF}^{*}$ & 31.39 & 8.5 \\
\hline Hordeum vulgare $\mathrm{L}$. & Barley & $24.22 \pm 6.24 \mathrm{DEFGH}$ & $56.78 \pm 10.10 \mathrm{BCDEF}$ & 29.66 & 6.77 \\
\hline Lens culinaris Medic. & Lentil & $26.93 \pm 6.34 \mathrm{FGH}$ & $53.53 \pm 9.61 \mathrm{ABCDE}$ & 32.91 & 10.02 \\
\hline Linum usitatissimum L. & Linseed & $25.36 \pm 7.51 \mathrm{EFGH}$ & $62.51 \pm 10.60 \mathrm{DEFG}^{*}$ & 23.93 & 1.04 \\
\hline Phaseolus vulgaris $\mathrm{L}$. & French bean & $12.59 \pm 6.20 \mathrm{ABCD}$ & $63.90 \pm 6.92 \mathrm{DEFG}$ & 22.54 & -0.35 \\
\hline Pisum sativum $\mathrm{L}$. & Pea & $15.08 \pm 2.37 \mathrm{ABCDEF}$ & $49.81 \pm 6.7 \mathrm{ABCD}^{* *}$ & 36.63 & 13.74 \\
\hline Raphanus sativus L. & Radish & $34.69 \pm 9.09 \mathrm{H}$ & $53.42 \pm 5.57 \mathrm{ABCDE}$ & 33.02 & 10.13 \\
\hline Solanum melongena $\mathrm{L}$. & Egg plant & $16.49 \pm 6.73 \mathrm{ABCDEF}$ & $59.44 \pm 2.65 \mathrm{CDEFG}$ & 27.00 & 4.11 \\
\hline Solanum tuberosum L. & Potato & $20.73 \pm 3.15$ BCDEFG & $68.45 \pm 7.57 \mathrm{FG}$ & 17.99 & -4.9 \\
\hline Trigonella foenum-graecum $\mathrm{L}$. & Fenugreek & $16.11 \pm 7.17 \mathrm{ABCDEF}$ & $42.46 \pm 5.06 \mathrm{~A}^{* *}$ & 43.98 & 21.09 \\
\hline Triticum aestivum $\mathrm{L}$. & Wheat & $15.20 \pm 4.21 \mathrm{ABCDEF}$ & $53.28 \pm 8.99 \mathrm{ABCDE}$ & 33.16 & 10.27 \\
\hline Vicia faba $\mathrm{L}$ & Faba bean & $11.82 \pm 7.85 \mathrm{ABC}$ & $65.19 \pm 7.34 \mathrm{EFG}$ & 21.25 & -1.64 \\
\hline Zea mays $\mathrm{L}$. & Maize & $18.99 \pm 8.00 \mathrm{ABCDEF}$ & $58.99 \pm 3.50 \mathrm{CDEFG}$ & 27.45 & 4.56 \\
\hline Fallow & & $12.39 \pm 1.54 \mathrm{ABCD}$ & $63.55 \pm 5.25 \mathrm{DEFG}$ & & \\
\hline Initial Viability & & & $86.44 \pm 2.29 \mathrm{H}$ & & \\
\hline
\end{tabular}

*Seeds with black embryo in one plot; **Seeds with black embryo in two plots

Viability loss due to (A) = soil factors and test crops, $(\mathrm{B})=$ test crops only 
Orobanche seed viability in Field-B also significantly reduced in all cases as in Field A. including control plots in comparison to initial viability (Table 3). But, reduction of Orobanche seeds buried in control plots did not differ significantly from the reduction in plots with most of the crops. The reduction was significant only with chili, fennel, radish, eggplant and maize. (Table 3). Among the different test crop investigated in field B, the reduction in Orobanche seed viability was highest in the plots with radish $(50.66 \%)$ and lowest in onion $(70.31 \%)$.

Table 3. Percentage reduction in seed bank, viability of Orobanche aegyptiaca seeds (\%) and its reduction after crop harvest in Field-B (Beldia). Same letters followed after the mean \pm standard deviation in a column do not differ significantly at $P=0.05$ according to Duncan's Multiple range tests followed after ANOVA.

\begin{tabular}{|c|c|c|c|c|c|}
\hline \multirow[t]{2}{*}{ Botanical name } & \multirow{2}{*}{$\begin{array}{c}\text { Common } \\
\text { name }\end{array}$} & \multirow{2}{*}{$\begin{array}{l}\text { \% Reduction in } \\
\text { seed bank }\end{array}$} & \multirow{2}{*}{$\begin{array}{c}\text { Viability }(\%) \\
\text { Mean } \pm \text { Sd }\end{array}$} & \multicolumn{2}{|c|}{ Viability loss (\%) } \\
\hline & & & & (A) & (B) \\
\hline Allium cepa $\mathrm{L}$. & Onion & $17.33 \pm 9.99 \mathrm{ABCD}$ & $70.31 \pm 6.19 \mathrm{~F}$ & 16.13 & -1.31 \\
\hline Allium sativum $\mathrm{L}$. & Garlic & $13.47 \pm 6.80 \mathrm{AB}$ & $68.60 \pm 4.47 \mathrm{EF}$ & 17.84 & 0.4 \\
\hline Capsicum frutescens $\mathrm{L}$. & Chili & $6.41 \pm 5.28 \mathrm{~A}$ & $58.68 \pm 6.65 \mathrm{ABCD}^{* *}$ & 27.76 & 10.32 \\
\hline Cicer arietinum $\mathrm{L}$. & Chickpea & $22.40 \pm 5.81 \mathrm{BCDE}$ & $65.12 \pm 7.00 \mathrm{CDEF}$ & 21.32 & 3.88 \\
\hline Coriandrum sativum $\mathrm{L}$. & Coriander & $19.73 \pm 4.96 \mathrm{ABCD}$ & $64.88 \pm 6.38 \mathrm{CDEF}$ & 21.56 & 4.12 \\
\hline Daucas carrota $\mathrm{L}$. & Carrot & $18.98 \pm 9.91 \mathrm{ABCD}$ & $69.55 \pm 4.5 \mathrm{~F}$ & 16.89 & -0.55 \\
\hline Fagopyrum esculentum Moench & Buckwheat & $19.89 \pm 7.84 \mathrm{ABCD}$ & $64.61 \pm 4.81 \mathrm{CDEF}^{*}$ & 21.83 & 4.39 \\
\hline Foeniculum vulgare Mill. & Fennel & $28.83 \pm 9.56 \mathrm{DEF}$ & $53.06 \pm 10.74 \mathrm{AB}^{*}$ & 33.38 & 15.94 \\
\hline Helianthus annus L. & Sunflower & $14.09 \pm 7.68 \mathrm{AB}$ & $69.40 \pm 7.67 \mathrm{~F}$ & 17.04 & -0.4 \\
\hline Hordeum vulgare $\mathrm{L}$. & Barley & $27.89 \pm 9.62 \mathrm{CDEF}$ & $57.18 \pm 5.16 \mathrm{ABC}$ & 29.26 & 11.82 \\
\hline Lens culinaris Medic. & Lentil & $35.39 \pm 1.83 \mathrm{~F}$ & $57.20 \pm 5.99 \mathrm{ABC}$ & 29.24 & 11.8 \\
\hline Linum usitatissimum L. & Linseed & $29.26 \pm 4.64 \mathrm{DEF}$ & $65.65 \pm 7.29 \mathrm{CDEF}$ & 20.79 & 3.35 \\
\hline Phaseolus vulgaris $\mathrm{L}$. & French bean & $15.08 \pm 3.28 \mathrm{ABC}$ & $66.04 \pm 3.38 \mathrm{DEF}$ & 20.4 & 2.96 \\
\hline Pisum sativum $\mathrm{L}$. & Pea & $17.45 \pm 8.26 \mathrm{ABCD}$ & $63.15 \pm 4.29 \mathrm{CDEF}$ & 23.29 & 5.85 \\
\hline Raphanus sativus L. & Radish & $34.96 \pm 5.00 \mathrm{EF}$ & $50.66 \pm 6.80 \mathrm{~A}$ & 35.78 & 18.34 \\
\hline Solanum melongena $\mathrm{L}$. & Egg plant & $11.31 \pm 4.60 \mathrm{AB}$ & $60.22 \pm 4.15 \mathrm{BCD}^{*}$ & 26.22 & 8.78 \\
\hline Solanum tuberosum L. & Potato & $15.13 \pm 8.04 \mathrm{ABC}$ & $68.68 \pm 3.97 \mathrm{EF}$ & 17.76 & 0.32 \\
\hline Trigonella foenum-graecum $\mathrm{L}$. & Fenugreek & $12.08 \pm 9.16 \mathrm{AB}$ & $69.00 \pm 4.12 \mathrm{~F}$ & 17.44 & 0 \\
\hline Triticum aestivum $\mathrm{L}$. & Wheat & $16.98 \pm 9.01 \mathrm{ABCD}$ & $62.84 \pm 7.91 \mathrm{CDEF}$ & 23.6 & 6.16 \\
\hline Vicia faba $\mathrm{L}$. & Faba bean & $17.64 \pm 1.19 \mathrm{ABCD}$ & $67.79 \pm 6.51 \mathrm{EF}$ & 18.65 & 1.21 \\
\hline Zea mays $\mathrm{L}$. & Maize & $13.66 \pm 4.89 \mathrm{AB}$ & $57.11 \pm 7.18 \mathrm{ABC}$ & 29.33 & 11.89 \\
\hline Fallow & & $15.40 \pm 3.02 \mathrm{ABC}$ & $69.00 \pm 5.75 \mathrm{EF}$ & & \\
\hline Initial Viability & & & $86.44 \pm 2.30 \mathrm{G}$ & & \\
\hline
\end{tabular}

*Seeds with black embryo in one plot; **Seeds with black embryo in two plots

Viability loss due to $(\mathrm{A})=$ soil factors and test crops, $(\mathrm{B})=$ test crops only 
Correlation between seed bank reduction and viability loss

When the data of Orobanche seed bank reduction and viability loss of the corresponding experimental conditions (pots, Field-A and FieldB) were processed through regression analysis using SPSS 15 statistical programme, it was observed that the reduction in Orobanche seed density was positively correlated with seed viability loss (Fig.1). $\mathrm{R}^{2}$ Obtained from the regression analysis of viability loss and seed bank reduction indicated that nearly $11 \%, 13 \%$ and $25 \%$ seed viability loss has contributed to the seed bank reduction in pot experiments, Field A and Field B, respectively. Regression analysis on combining data of all three experiments, indicated that the viability loss of Orobanche seed contributes only nearly $24 \%$ on seed bank reduction. When the viability loss due to soil factors and test crops together was compared with the value obtained in control treatment, it was found that the contribution of edaphic factors was about $75 \%$ and that of test crops were about $25 \%$, respectively, for the viability loss.
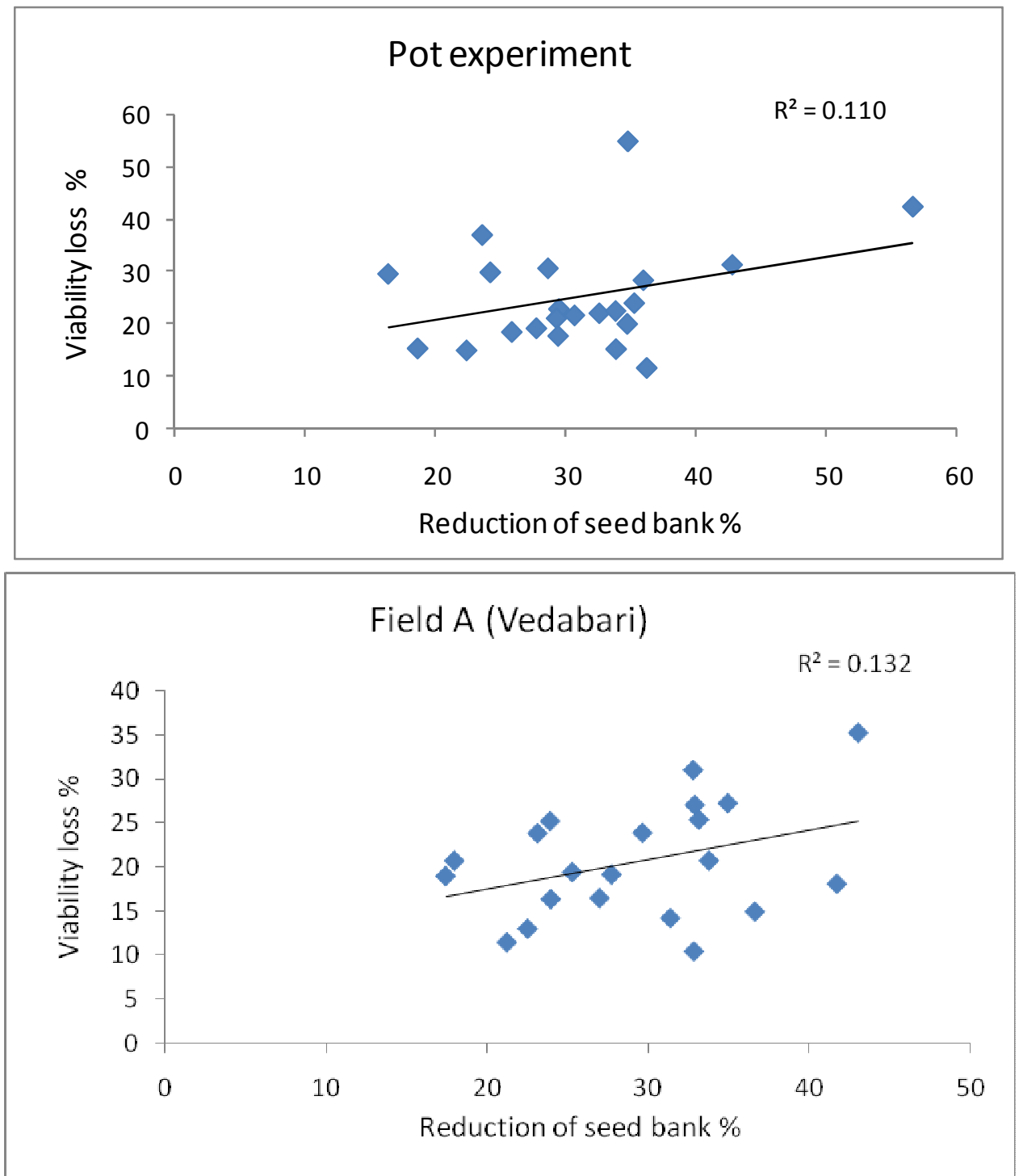

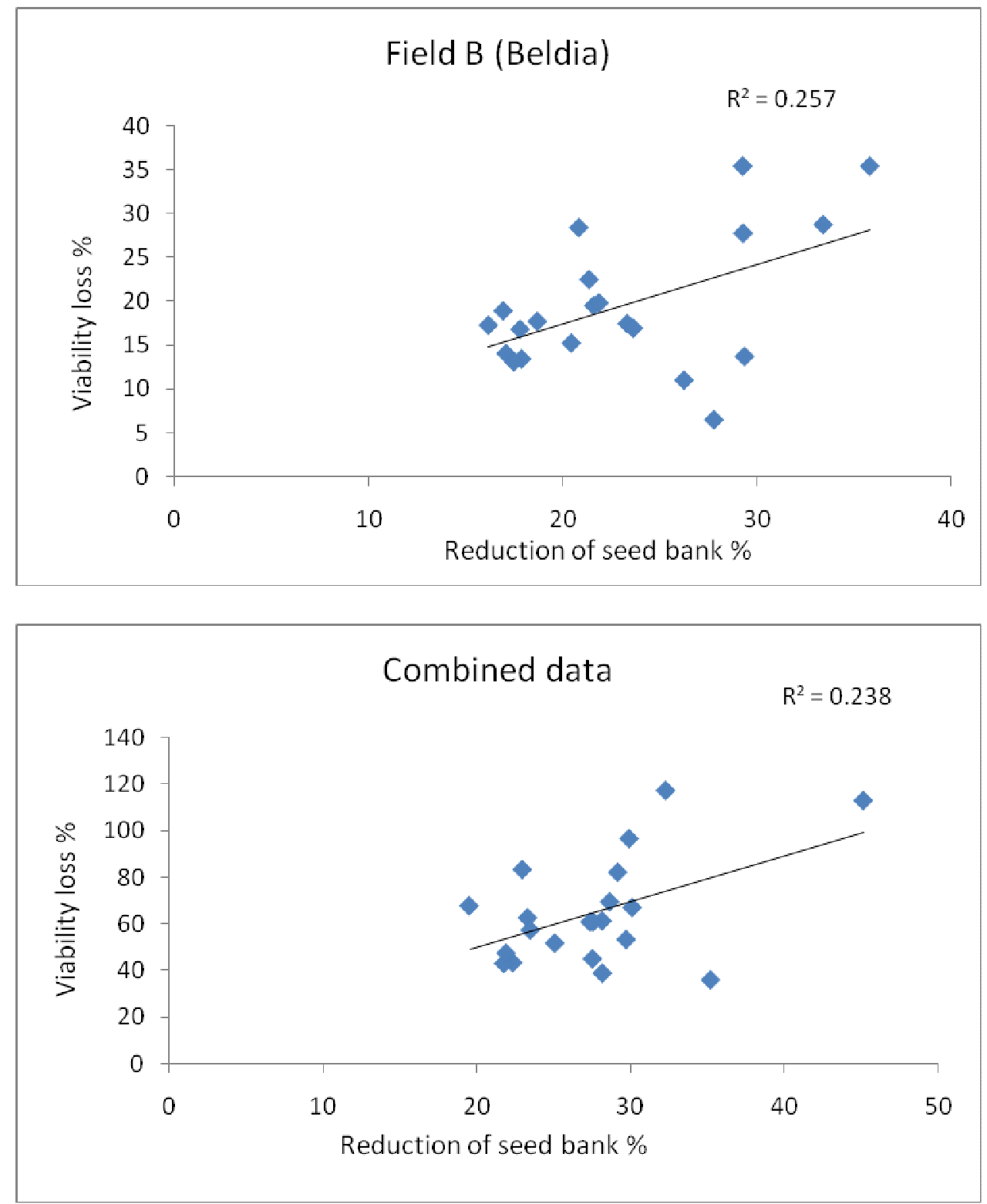

Fig 1. Relation between Orobanche seed bank reduction and viability loss in soil under different experimental conditions.

\section{DISCUSSION AND CONCLUSIONS}

High seed viability loss of buried Orobanche seeds was observed in pots and field A. High root density in the pots must be the reason for highest reduction in seed viability. Possibly the root exudates of the non-host crop must have initiated seed germination but later the germinated seeds could not infest the roots of test crop, as a result the germinated seeds must have died and contributed in seed bank reduction. Similarly more viability loss of buried seed in Field A is due to infection of microorganism in soil, as infected seeds are more observed in Field A than in Field B. 
Data have also indicated that both edaphic factors and test crops are responsible for the loss in Orobanche seed viability. In this regard it could be assumed that soil microorganisms reduce Orobanche seed viability either by infection or by stimulating seed germination as reported by Cezard (1973). The possible role of non-host test crops in reducing Orobanche seed viability could be that, i) crops exude stimulant(s) for suicidal seed germination (Chabrolin 1935, Kasasian 1971, Edwards 1972, Krishnamurty et al. 1977, Sauerborn 1991), and ii) crops exude chemicals which in association with suitable microorganisms acquire stimulatory nature for Orobanche seed germination as mentioned by Wegmann (1991).

The Orobanche seed bank reduction in soil is positively correlated with viability loss in all the experimental conditions. From the regression analysis $R^{2}$ value obtained in Field $B$ is higher than in Field A or pot experiment. This indicates the relationship between viability loss (\%) and seed bank reduction is higher in Field B (Beldia) than in Field A (Vedabari). The soil type in Field A (Vedabari) is sandy loam and in Field B (Beldia) is loamy soil. Possibly the root exudates of test crop could have retained in loamy soil for longer time than in sandy loam soil and have contributed in higher relationship because of suicidal germination.

\section{ACKNOWLEDGEMENTS}

Author like to thank Professor S.C. Srivastava, Associate Professor Dr. G.B. Khattri and Professor M.K. Chettri for their valuable guidance and suggestions. The author also like to thank Campus chief and Head of Department of Botany, Amrit Campus, for providing necessary laboratory facilities.

\section{REFERENCES}

Aalders, A.J.G. and R. Pieters. 1986. Plant vigour as a misleading factors in the search for resistance in broad bean to Orobanche crenata. In: Proceedings of a Workshop on Biology and Control of Orobanche. (ed.) S.J. ter Borg. Lh/VPO, Wageningen, Netherlands, pp. 140-149.

Abbes, Z.Z., M. Kharrat and W. Chaibi. 2008. Seed germination and tubercle development of Orobanche foetida and $O$. crenata in presence of different plant species. Tunisian Journal of Plant Protection 3(2):101-109.

Acharya, B.D., A. Bista, G.B. Khattri, M.K.Chettri and S.C. Srivastava. 2003. A method of quantitative estimation of Orobanche seeds from infested soil and its reliability test. Ecoprint 10(1):53-57.

Ashworth, L.J. 1976. Quantitative detection of branched broomrape in California tomato soils. Plant Disease Reporter 60:380-383.

Brown, R., A.D. Greenwood, A.W. Johnson, A.G. Long and A.R. Lansdowne. 1951. The stimulant involved in the germination of Orobanche minor Sm. Chromatographic purification of crude concentrates. Journal of Biochemistry 48:564-574.

Cezard, R. 1973. Quelques aspect particuliers de la biologie des Orobanches. Proc. EWRS Symp. Parasitic Weeds, Malta, pp. 55-67.

Chabrolin, C. 1935. Germination des graines et plantes-hotes de Orobanche de la feve (Orobanche speciosa D.C.). C.r. hebd. Seanc. Acad. Sci., Paris, 200:1974-1976.

Cubero, J.I. and M.T. Moreno, 1979. Agronomic control and sources of resistance in Vicia faba to Orobanche spp. In: Some Current Researches on Vicia faba in Western Europe. (eds.) Bond, D.A., G.T. Scarascia Mugnozza and M.H. Poulsen. Commission of The European Communities. pp. 41-80. 
Edwards, W.G.H. 1972. Orobanche and Other Plant Parasite Factors. Harborne, J.B. (ed.) Phytochemical Ecology, Academy Press. pp. 235-248.

Kadry, A.R. and H. Tewfic. 1956. Seed germination in Orobanche crenata Forsk. Svensk Bot. Tidskr. 50:270-286.

Kasaisian, L. 1971. Orobanche spp. PANS 17:3541.

Khattri, G.B. 1997. Some Studies on biology and control of Orobanche in Brassica crops. A Thesis submitted for the Degree of Doctor of Philosophy in Botany (Faculty of Science) to the B.R.A. Bihar University Muzaffarpur, Bihar, India, 157 pp.

Krishnamurty, G.V.G., R. Lal and K. Nagarjan. 1977. Further studies on the effect of various crops on the germination of Orobanche seed. PANS 23:206-208.

Ma, Y.Q., W. Zhang, S.Q. Dong, X.X. Ren, Y. An and M. Lang. 2012. Induction of seed germination in Orobanche spp. by extracts of traditional Chinese medicinal herbs. Sci. China
Life Sci. 55:250-260, doi: 10.1007/s11427012-4302-2

Musselman, L.J. 1980. The biology of Striga, Orobanche and other root parasites. Ann. Rev. Phytopathology 18:463-489.

Parker, C. and C.R. Riches.1993. Parasitic Weeds of the World: Biology and Control. CAB International, Wallingford, UK.

Puzzilli, M. 1983. Tobacco broomrape and their control and some useful references to other parasite and host species. Rev. Agric. Subtropicale e Tropicale 78:209-248.

Sauerborn, J. 1991. Parasitic Flowering Plants, Ecology and Management. Supra-regional project, GTZ, University of Hohenheim, Institute of Plant Production in the Tropics and Subtropics. Verlag josef margraf Scientific book.

Wegmann, K., E. Von Elert, H.J. Harloff and M. Stadler. 1991. Tolerance and resistance to Orobanche. In: Progress in Orobanche Research. (eds.) Wegmann, K. and L.J. Musselman. Eberhard Karls Universitat. 